\title{
NOVICE TEENAGE DRIVER CELL PHONE USE PREVALENCE
}

\author{
Johnathon Ehsani, Ashley Brooks-Russell, Kaigang Li, Jessamyn Perlus, Anuj Pradhan \& Bruce \\ G. Simons-Morton \\ National Institutes of Health \\ Bethesda, Maryland, USA \\ Email: johnathon.ehsani@nih.gov
}

\begin{abstract}
Summary: Novice teenage drivers have high crash rates due to inexperience; therefore, cell phone-related secondary task engagement (distracted driving) is likely to aggravate crash risk for this population. A previous study of teenage distracted driving behavior, found that $34 \%$ of $16-17$ - year-olds had texted, and $52 \%$ reported talking on a cell phone while driving (Madden \& Lenhart, 2009). In the current study, data from the NEXT Generation Health Study were analyzed to estimate the prevalence of cell phone-related distracted driving in a nationally representative sample of U.S. eleventh grade students, the age when most teenagers are first eligible to receive a license to drive independently. Using the subsample of teenagers that reported having a license that allowed independent, driving ( $n=881$ ), the prevalence of cell phone-related distracted driving was estimated. Nationwide, four out of five (80.0\%) teenage drivers reported making or receiving a call, and $72.0 \%$ reported sending or receiving a text message at least one day in the past 30 days. In addition, teenagers reported talking on 32.6\% and texting on $40.3 \%$ of the days they drove. Access to a vehicle, the number of miles teenagers drove each day (the more driving the more phone use), and race/ethnicity (Asians had lower cell phone use than Whites, Hispanics, or African-Americans), were significantly associated with cell phone-related distracted driving. These findings indicate a higher prevalence of teenage cell phone use while driving than previous studies. More research is needed to understand predictors, safety outcomes, and prevention approaches for teenage distracted driving.
\end{abstract}

\section{INTRODUCTION}

A growing body of evidence links cell phone-related secondary task engagement (distracted driving) to an elevated risk of motor vehicle crashes. Naturalistic driving has demonstrated that secondary tasks that take the driver's eyes off the forward roadway, such as dialing and texting, increase crash risk and the longer the glance the greater the risk (Simons-Morton \& Klauer, 2012). A driving simulator study reported that cell phone use slowed reaction time by $18 \%$ and doubled the likelihood of a rear-end collision (Strayer \& Drews, 2004).

Novice teenage drivers have especially high crash rates due to inexperience. Therefore, cell phone-related distraction is likely to entail greater risk for novices than experienced drivers (Hedlund, 2007; Ferguson, 2003). Two previous national surveys have reported the prevalence of cell phone-related distracted driving among 16- and 17-year-old drivers. The Teens and Distracted Driving study by the Pew Research Center reported that 34\% of teenagers aged 16-17 years had texted while driving and 52\% reported talking on a cell phone while driving (Madden 
et al., 2009). The Youth Risk Behavior Surveillance (YRBS) survey found that $42.9 \%$ of teenagers in $11^{\text {th }}$ grade (corresponding to the same age group of the current study) had reported texting or emailing while driving (Eaton et al., 2012).

These two nationally representative survey studies of 16- and 17-year-olds included limited measures of self-reported distracted driving that may not have captured the full range or prevalence of cell phone-related behaviors. The Pew Research Center study asked respondents if they have "ever engaged in the behavior" (Madden et al., 2009), an item that is unable to determine the persistence of the behavior over time. The YRBS did not ask respondents about making or receiving calls, but asked, "During the past 30 days, on how many days did you text or e-mail while driving a car or other vehicle," which does not including phone use or distinguish texting from emailing. The purpose of the current study is to describe cell phone-related distracted driving in a nationally representative sample of novice teenage drivers, using survey items that capture multiple dimensions of cell phone-related behavior.

\section{METHODS}

\section{Sampling}

Data were from the second (2011) annual wave of a survey of a nationally representative cohort of high school students from the NEXT Generation Health study. The first wave of this cohort study began when students were in 10th grade. Students were sampled using a three-stage stratified clustered sample strategy, with school districts as the primary sampling unit. African American students were oversampled to improve the population estimate. Students completed questionnaires in the spring of $11^{\text {th }}$ grade, the age when most teenagers are first eligible to receive a license to drive independently. Students were given the opportunity to complete the survey online. If they were unable to do so, a hard copy was completed at school when a research staff member visited the school. The study protocol was approved by the Institutional Review Board of the Eunice Kennedy Shriver National Institute of Child Health and Human Development.

For the current study, the analyses were restricted to participants who reported being licensed for independent, unsupervised driving $(n=881)$. There were no significant differences in age or gender between those who reported having a license to drive independently (licensed) to those were not (unlicensed). A significantly higher proportion of licensed drivers were White, came from high affluence households, and had higher vehicle access (access to a vehicle most or all of the time) relative to those who were unlicensed.

\section{Dependent variables}

Cell phone use while driving was measured using four items: On how many days in the last 30 days while driving have you (a) answered a call on your cell phone, (b) made a call on your cell phone, (c) read text messages, and (d) sent text messages? Answering and receiving calls were combined to form a single variable related to talking on the phone (talking). Similarly, reading and sending text messages were combined to form a single variable related to texting behavior (texting). 
To compare the findings of this study to the existing literature, cell phone use while driving was coded at least one day in the last 30 days and not at all during the last 30 days. A second measure of cell phone use while driving was the proportion of days a cell phone was used while driving. This was calculated by dividing the number of days a cell phone was used while driving in the last 30 days by the number of days a vehicle was driven in the last 30 days.

\section{Independent variables}

Participants reported their age, gender, and racial/ethnic background. Family socioeconomic status was estimated using the Family Affluence Scale (Currie et al., 2004) which includes measures of the number of cars owned, computers owned, whether the student had his/her own bedroom, and the number of family vacations in the last 12 months for each household. Students were then categorized as low, moderate and high affluence (Spriggs, Iannotti, Nansel, \& Haynie, 2007). Vehicle access was measured using a single item "How much time during the last 30 days have you had access to a vehicle that you can drive?" Response options included "never," "some," "most," or “all.” Responses were categorized as low (never or some) and high (most and all). Driving exposure was estimated using the item "On average, about how many miles did you drive each day you drove?” Responses were categorized into three levels: low (less than 10 miles each day), moderate (10 to 20 miles each day), and high (20 miles or more each day).

\section{Analysis}

Statistical analyses were performed using SAS 9.3. Features of complex survey design (i.e., stratification, clustering and longitudinal sampling weights) were taken into account in all procedures. Domain analysis, referring to the computation of statistics for subpopulations in addition to the computation of statistics for the entire study population, was used for describing the distracted driving behavior of teenage drivers.

\section{RESULTS}

Nationwide, four out of five (80.0\%) teenage drivers reported talking while driving, and 72.0\% reported texting while driving at least one day in the last 30 days (Table 1). Overall, the prevalence of talking or texting while driving at least once in the last 30 days was lower among Asians than Whites, Hispanics and African-Americans. Those with high vehicle access were significantly more likely to have talked or texted while driving, relative to those with low vehicle access. 
Table 1. Prevalence of teenage cell phone use at least once in the last 30 days $(n=881)$

\begin{tabular}{|c|c|c|c|c|}
\hline & \multicolumn{2}{|c|}{ Talking } & \multicolumn{2}{|c|}{ Texting } \\
\hline & $\%$ & $95 \% \mathrm{CI}$ & $\%$ & $95 \% \mathrm{CI}$ \\
\hline Total & 80.0 & {$[75.3-84.6]$} & 72.0 & {$[67.6-76.4]$} \\
\hline \multicolumn{5}{|l|}{ Gender } \\
\hline Male & 78.8 & {$[72.9-84.6]$} & 69.7 & {$[63.1-76.4]$} \\
\hline Female & 81.1 & {$[75.1-87.1]$} & 74.1 & {$[67.9-80.3]$} \\
\hline \multicolumn{5}{|l|}{ Race } \\
\hline White & $80.9^{\mathrm{a}}$ & {$[75.0-86.8]$} & $73.3^{\mathrm{a}}$ & {$[67.9-78.8]$} \\
\hline Hispanic & $76.5^{\mathrm{a}}$ & {$[57.4-95.6]$} & $69.6^{\mathrm{a}}$ & {$[53.0-86.1]$} \\
\hline African-American & $83.0^{\mathrm{a}}$ & {$[73.8-92.3]$} & $74.6^{\mathrm{a}}$ & {$[62.2-87.0]$} \\
\hline Asian & 31.4 & {$[7.3-55.5]$} & 20.8 & {$[0.3-41.2]$} \\
\hline Hawaiian & $95.3^{\mathrm{a}}$ & {$[85.0-100.0]$} & $82.2^{\mathrm{a}}$ & {$[48.9-100.0]$} \\
\hline American Indian & 76.8 & {$[53.6-100.0]$} & 59.1 & {$[19.9-98.3]$} \\
\hline \multicolumn{5}{|l|}{ Family Affluence } \\
\hline Low & 79.0 & {$[70.4-87.7]$} & 63.3 & {$[50.1-76.6]$} \\
\hline Moderate & 77.6 & {$[72.4-82.7]$} & 72.1 & {$[67.2-77.1]$} \\
\hline High & 83.4 & {$[76.2-90.6]$} & 74.9 & {$[68.2-81.7]$} \\
\hline \multicolumn{5}{|l|}{ Vehicle Access } \\
\hline Low & 58.2 & {$[43.1-73.3]$} & 45.6 & {$[27.4-63.9]$} \\
\hline High & $82.9^{\mathrm{b}}$ & {$[78.6-87.2]$} & $75.5^{\mathrm{b}}$ & {$[71.9-79.2]$} \\
\hline \multicolumn{5}{|l|}{ Driving Exposure } \\
\hline Low (< 10 miles) & 72.1 & {$[63.2-81.1]$} & 68.1 & {$[60.0-76.2]$} \\
\hline Medium (10 - 20 miles) & 86.2 & [79.9-92.5] & 71.7 & [63.5 - 79.9] \\
\hline High ( $>20$ miles $)$ & 85.6 & [80.8 - 90.5] & 78.5 & [73.3 - 83.8] \\
\hline
\end{tabular}

Teenagers reported talking on $32.6 \%$ of the days they drove and texting on $40.3 \%$ of the days they drove (Table 2). Overall, the percentage of days talking and texting while driving was higher among African-Americans than Asians and Hawaiians. Those with high vehicle access reported texting on a significantly higher proportion of days than those with low vehicle access. Those who drove more than 10 miles each day reported talking on a higher percentage of days than those who drove less than 10 miles. Similarly, those who drove more than 20 miles each day reported texting a significantly higher proportion of days than those who drove less than 10 miles each day.

Table 2. Percentage of days a cell phone was used while driving relative to days driven in the last 30 days $(n=881)$

\begin{tabular}{|c|c|c|c|c|}
\hline & \multicolumn{2}{|c|}{ Talking } & \multicolumn{2}{|c|}{ Texting } \\
\hline & $\%$ & 95\% CI & $\%$ & 95\% CI \\
\hline Total & 32.6 & [28.6 - 36.7] & 40.3 & {$[36.8-43.8]$} \\
\hline \multicolumn{5}{|l|}{ Gender } \\
\hline Male & 34.2 & [28.8 - 39.7] & 40.7 & [34.9-46.4] \\
\hline Female & 31.2 & [26.8 - 35.5] & 40.0 & [35.9-44.2] \\
\hline \multicolumn{5}{|l|}{ Race } \\
\hline White & 32.1 & {$[27.6-36.6]$} & 40.2 & {$[36.2-44.2]$} \\
\hline Hispanic & 29.4 & {$[21.4-37.3]$} & 38.6 & {$[27.5-49.6]$} \\
\hline African-American & 45.5 & {$[35.7-55.2]$} & 48.6 & [39.9-57.2] \\
\hline Asian & $14.9^{\mathrm{a}}$ & {$[0.7-29.0]$} & $12.0^{\mathrm{a}}$ & {$[-2.6-26.6]$} \\
\hline Hawaiian & $18.0^{\mathrm{a}}$ & {$[7.0-29.1]$} & $25.7^{\mathrm{a}}$ & {$[13.9-37.5]$} \\
\hline American Indian & 24.7 & {$[2.6-46.1]$} & 37.4 & {$[15.4-59.4]$} \\
\hline \multicolumn{5}{|l|}{ Family Affluence } \\
\hline Low & 32.7 & {$[26.3-39.4]$} & 27.4 & [24.6 - 50.2] \\
\hline Moderate & 30.9 & {$[26.2-35.7]$} & 38.7 & [34.5 - 42.9] \\
\hline High & 34.8 & {$[28.9-40.7]$} & 43.4 & [35.9-50.9] \\
\hline
\end{tabular}




\begin{tabular}{|c|c|c|c|c|}
\hline \multicolumn{5}{|l|}{ Vehicle Access } \\
\hline Low & 22.7 & {$[14.8-30.6]$} & 23.0 & [13.3-32.7] \\
\hline High & 34.0 & {$[29.7-38.2]$} & $42.6^{\mathrm{b}}$ & [39.2-46.1] \\
\hline \multicolumn{5}{|l|}{ Driving Exposure } \\
\hline Low (< 10 miles) & 24.6 & [13.9-35.3] & 28.8 & [19.1 - 38.5] \\
\hline Medium (10 - 20 miles) & $30.2^{\mathrm{b}}$ & {$[21.6-38.8]$} & 34.0 & [24.3-43.7] \\
\hline High ( $>20$ miles) & $34.8^{\mathrm{b}}$ & {$[30.5-39.1]$} & $43.9^{\mathrm{b}}$ & {$[40.1-47.7]$} \\
\hline
\end{tabular}

\section{DISCUSSION}

Cell phone related distracted driving is highly prevalent among novice teenage drivers in the United States. The prevalence estimates observed in this nationally representative sample are higher than previously reported studies. Overall, 80.0\% of drivers reported talking while driving, and $72.0 \%$ reported texting while driving at least one day in the last 30 days. This compares with $52 \%$ of teenagers reporting talking and $26 \%$ of teenagers reporting texting in the last 30 days in the study by Madden and colleagues (2009). The differences could represent a change in phone use behaviors, consistent with the dramatic increase in smart phone use among teenagers (Nielsen.com, 2012). Alternatively, these differences could be due to methodological differences in sampling between this study and previous studies. In the current study, analyses were limited to subsample of $11^{\text {th }}$ grade students who reported being licensed for independent, unsupervised driving. In contrast, the report by Madden et al was based on a sample of 16- and 17-year-old cell phone users, and YRBS estimate was based on a nationally representative sample of all eleventh graders.

This study found that teenagers with greater vehicle access and higher driving exposure (measured as miles driven) were significantly more likely to use a cell phone for talking and texting while driving. While vehicle access was previously found to be associated with cell phone use while driving among teenagers (García-España, Ginsburg, Durbin, Elliott, \& Winston, 2009), this is one of the first studies to report a positive association between driving exposure and cell phone use while driving in this population.

As the majority of $11^{\text {th }}$ grade students live at home, there may be a role for parents to establish expectations with respect to cell phone related distracted driving. Previous studies have established the effectiveness of parental monitoring and limit setting with respect to high-risk driving situations such as driving at night, and driving with peer passengers, using parent-teen driving agreements (Simons-Morton, Hartos, Leaf, \& Preusser, 2006). These could be extended to include cell phone use while driving. Parental management has also been shown to be more effective in a state with Graduated Driver Licensing (GDL) compared with a state without GDL (Hartos, Simons-Morton, Beck, \& Leaf, 2005). Therefore, the combination of GDL with provisions limiting distracted driving and increased parental management might reduce prevalence of distracted driving and increase safety.

The high prevalence of cell phone-related distracted driving among teenagers is striking when taking into account that many jurisdictions across the United States have in recent years restricted the use of cell phones while driving for newly licensed teenage drivers (Ibrahim, Anderson, Burris, \& Wagenaar, 2011). While the effectiveness of distracted driving laws on 
teenage crashes has not been established, these findings suggest that many licensed young drivers may routinely violate distracted driving laws. It is likely that teenage driver cell phone use could be reduced through legislation that applies to all drivers and other norm setting strategies. Future studies should compare the prevalence of cell phone use in states with restrictions for teenage cell phone use while driving, relative to states without legislation.

There are several limitations to this study that should be noted. The findings were based on selfreported behaviors, which are subject to reporting bias and may underestimate the prevalence of cell phone related distracted driving. The measures of cell phone related distracted driving did not fully capture the frequency of the behavior, only the number days on which the behavior occurred, limiting our ability to quantify the exposure to risk. Finally, the recruitment of the sample for the study was based on the grade of the respondents, rather than their age. A strength of the study is the large nationally representative sample of high school students, providing a contemporary estimate of cell phone related distracted driving among teenagers in the United States.

This study extends what is known about cell phone related distracted driving by providing both a prevalence estimate, as well as a measure of the regularity of the behavior. When considered together, these measures provide a nuanced picture of cell phone related behaviors. In addition, this study confirms the association between vehicle access and cell phone use while driving, and reports the previously unknown association between driving exposure (measured as the number of miles driven) and cell phone use while driving. Given the well-established risk of secondary tasks, the increasing market penetration of smart phones, particularly among youth, and the growing number of other in-vehicle distractions, our findings have implications for safety. Additional research is needed on predictors, safety outcomes, and effective prevention approaches for distracted driving among teens.

\section{ACKNOWLEDGMENT}

This research (contract number HHSN267200800009C) was supported in part by the Intramural Research Program of the Eunice Kennedy Shriver National Institute of Child Health and Human Development (NICHD), and the National Heart, Lung and Blood Institute (NHLBI), the National Institute on Alcohol Abuse and Alcoholism (NIAAA), and Maternal and Child Health Bureau (MCHB) of the Health Resources and Services Administration (HRSA), with supplemental support from the National Institute on Drug Abuse (NIDA).

\section{REFERENCES}

Currie, C., Roberts, C., Morgan, A., Smith, R., Settertobulte, W., Samdal, O. et al. (2004). Young people's health in context. Health behaviour in school-aged children (HBSC) study: international report from the 2001/2002 survey (Rep. No. 4). Copenhagen, Denmark: World Health Organization.

Eaton, D. K., Kann, L., Kinchen, S., Shanklin, S., Flint, K. H., Hawkins, J. et al. (2012). Youth risk behavior surveillance - United States, 2011 (Rep. No. 61). 
Ferguson, S. A. (2003). Other high-risk factors for young drivers - how graduated licensing does, doesn't or could address them. Annual proceedings - Association for the Advancement of Automotive Medicine, 47, 539-542.

García-España, J. F., Ginsburg, K. R., Durbin, D. R., Elliott, M. R., \& Winston, F. K. (2009). Primary access to vehicles increases risky teen driving behaviors and crashes: National perspective. Pediatrics, 124, 1069-1075.

Hartos, J. L., Simons-Morton, B. G., Beck, K. H., \& Leaf, W. A. (2005). Parent-imposed limits on high-risk adolescent driving: Are they stricter with graduated driver licensing? Accident Analysis and Prevention, 37, 557-562.

Hedlund, J. (2007). Novice teen driving: GDL and beyond. Journal of Safety Research, 38, 259266.

Ibrahim, J. K., Anderson, E. D., Burris, S. C., \& Wagenaar, A. C. (2011). State laws restricting driver use of mobile communications devices: Distracted-driving provisions, 19922010. American Journal of Preventive Medicine, 40, 659-665.

Madden, M. \& Lenhart, A. (2009). Teens and distracted driving Washington D.C.: Pew Research Center.

Nielsen.com (2012). Young Adults Lead Growth Among Smartphone Owners. Nielsen Wire [On-line]. Available: http://blog.nielsen.com/nielsenwire/online_mobile/young-adults-andteens-lead-growth-among-smartphone-owners/

Simons-Morton, B. G., Hartos, J. L., Leaf, W. A., \& Preusser, D. F. (2006). The effects of the checkpoints program on parent-imposed driving limits and crash outcomes among Connecticut novice teen drivers at 6-months post-licensure. Journal of Safety Research, 37, 9-15.

Simons-Morton, B. G. \& Klauer, S. G. (2012). Contribution of Cell Phone Use and Other Secondary Tasks to Crashes and Near Crashes Among Adult and Teenage Drivers. Presented at the Annual Meeting of American Public Health Association San Francisco, CA Oct., 29 2012.

Spriggs, A. L., Iannotti, R. J., Nansel, T. R., \& Haynie, D. L. (2007). Adolescent Bullying Involvement and Perceived Family, Peer and School Relations: Commonalities and Differences Across Race/Ethnicity. Journal of Adolescent Health, 41, 283-293.

Strayer, D. L. \& Drews, F. A. (2004). Profiles in driver distraction: Effects of cell phone conversations on younger and older drivers. Human Factors, 46, 640-649. 